\title{
Perheet vai poliitikot peruskoulua säätämässä?
}

\author{
Seppänen, P.; Kalalahti, M.; Rinne, R.; Simola, H. (toim.) (2015). \\ Lohkoutuva peruskoulu. Perheiden kouluvalinnat, yhteiskuntaluokat ja koulutuspolitiikka. \\ Suomen kasvatustieteellinen seura: Kasvatusalan tutkimuksia 68. $544 \mathrm{~s}$. \\ ISBN 978-952-5401-70-7
}

PERUSKOULUSTA ON PIENELLÄ VIIVEELLÄ, OECD:n PISAtutkimusten siivittämänä, ehditty tehdä yksi suomalaisen koulutusviennin brändituote. Lohkoutuva peruskoulu -teoksen kirjoittajat väittävät kuitenkin, että tuote on ehtinyt vuosien varrella pahasti pilaantumaan, ainakin jos sen tärkeimpänä ainesosana pidetään koulutuksellista tasa-arvoa.

Teos pohjautuu Helsingin ja Turun yliopistoissa toteutettuihin tutkimushankkeisiin Vanhemmat ja kouluvalinta. Perheiden koulutusstrategiat, eriarvoistuminen ja paikalliset koulupolitiikat suomalaisessa peruskoulussa (2009-2012) sekä Parents and School Choice. Family Strategies, Segregation and School Politics in Chilean and Finnish Basic Schooling (2010-2013).

Kirja on aikamoinen järkäle, vaikka omasta kappaleestani harmittavasti puuttuikin sisällysluettelossa luvattu kirjoittajaluettelo. Vaikka toimittajat puhuvat teoksen luvuista, lukijasta se vaikuttaa pikemminkin kolmentoista kirjoittajan eri kokoonpanoissa tuottaman viidentoista artikkelin kokoelmalta kuin tutkimustulosten systemaattiselta yhteenvedolta. Kaikki artikkelit perustuvat tutkimushankkeissa kerättyihin aineistoihin, joskin monissa vedotaan myös muihin aiheeseen liitty- viin laki- ja viranomaisteksteihin ja aiempaan tutkimuskirjallisuuteen.

Artikkelimainen toteutus koettelee lukijan voimia, sillä jokainen kirjoitelma on rakennettu erillisen tutkimusraportin tapaan taustoituksineen, teoretisointeineen, aineistojen esittelyineen ja analysointeineen ja johtopäätöksineen. Tästä aiheutuu myös pitkin matkaa tarpeetonta toistoa.

Teos on jaettu eri osiin: Kouluvalintapolitiikka Suomessa ja kaupungeissa, Koulupolitiikka ja vanhemmat, Kouluvalinta ja yhteiskuntaluokka sekä johtopäätöslukuun.

\section{KOULUVALINTAPOLITIIKKAA, KOULUPOLITIIKKAA VAI KOULUTUSPOLITIIKKAA?}

Ensimmäisessä osassa Piia Seppänen ja Risto Rinne kuvailevat anglosaksista, OECD:n edistämää koulutuksen kilpailutus- ja markkinoistamispolitiikkaa. Teoksen taustalla olleissa tutkimushankkeissa tämän politiikan on tulkittu ehdollistavan kansalliset ja alueelliset koulupolitiikat.

Tutkimuksen peruskäsitteiden, asetelman ja aineistojen esittelyn sijasta kirjoittajat avaavat kouluvalikointi-ilmiön suomalaista historiaa musiikkiin erikoistuneiden luokkien kautta. Kiintoisuudestaan huolimatta ratkaisu vaikuttaa hiukan oudolta. Avausluvulta olisi odottanut kokonaisvaltaisempaa tutkimusasetelman, keskeisten käsitteiden ja kontekstin jäsennystä.

Tätä palvelevat seuraavat kolme artikkelia. Janne Varjo, Mira Kalalahti ja Piia Seppänen ottavat käyttöön "institutionaalisten kouluvalintatilojen" käsitteistön ja luonnehtivat Helsingin, Espoon, Vantaan, Tampereen ja Turun kaupunkien oppilasvalinnan periaatteita, painotetun opetuksen tarjontaa yläkouluissa sekä (vielä esittelemättömään aineistoon perustuvia) vanhempien mielipiteitä vaikutusmahdollisuuksistaan ja tarjonnan laadukkuudesta. Kaupungit näyttävät profiileiltaan varsin erilaisilta, joten lukija virittyy odottamaan perusteluita niiden valinnalle.

Hannu Simola, Piia Seppänen, Sonja Kosunen ja Heidi Vartiainen esittelevät yhdessä teoksen kiinnostavimmista artikkeleissa viranomais- ja lakitekstejä hyödyntäen koulutuksellisen tasa-arvon valikointiin perustuvia tulkintoja.

Artikkelissa kuvataan peruskoulun alkuajoilta tuttuja tasokursseja. Vasta niiden purkaminen tuotti peruskoulun sosiaalisen tasa-arvon, sosiaalisen sekoittamisen periaatteen ja pyrkimyksen oppilaskohtaiseen arviointiin. 1980-lopulla puhe siirtyi yksilölliseen tasa-arvoon sekä perheiden ja oppilaan oikeuteen 
lahjakkuutensa mukaiseen opetukseen. 2010-luvulla se muuntui puheeksi osallistavasta tasa-arvosta. Tämä tarkoitti pyrkimystä opetuksen ja oppimisen yksilöllisyyteen, jonka arviointiin tarvittiin kuitenkin laajeneva pedagogisten asiantuntijoiden joukko.

Tutkimusaineistolähtöinen tarkastelu ei pysy historiallisen johdatuksen tasolla ja esimerkkikaupunkien tasa-arvopolitiikkojen kuvaus jää muutaman kouluvalintatiedon varaan. Valitettavasti artikkelin tematiikkaan ei jatkossa juuri palata.

Janne Varjon, Mira Kalalahden ja Heikki Silvennoisen artikkeli esittelee sivistyksellisiä oikeuksia ja vapauksia koskevaa kirjallisuutta sekä vanhempien mielipiteitä koulutusoikeuksista ja vapauksista. Ikävää hämmennystä aiheuttaa oikeuksia ja vapauksia koskevien väittämien kuvausten sekaantuminen sivulla 129. Hämmentävää on myös yhteiskuntaluokkien tuominen tarkasteluun, kun aihetta käsitellään varsinaisesti vasta teoksen loppupuolella.

Siitä huolimatta kiintoisa löydös on kaikkien yhteiskuntaluokkien vanhempia yhdistävä asenne, joka korostaa yhtäläisiä oikeuksia koulutukseen vapauksien sijaan. Pieniä eroja tulkitaan vanhempien poliittisten kantojen ja anglosaksiseen kirjallisuuteen perustuvien, aikakauden luonnetta koskevien spekulaatioiden avulla.

\section{VANHEMMAT KOULUVALINNOISSA}

Osa Koulupolitiikka ja vanhemmat nojautuu edellistä lukua sys- temaattisimmin tutkimusaineistoon. Teoksen analyyttisesti ehkä painavin on Piia Seppäsen, Sonja Kosusen, Heidi Vartiaisen ja Virve Murron artikkeli. Se esittelee Espoossa, Vantaalla ja Turussa toteutetut vanhempien haastattelut ja analysoi, millaisin puhetavoin niissä oikeutetaan kouluun sijoittamista ja opintoja koskevia politiikkoja ja valintoja. Analyysiä taustoitetaan tässä, kuten koko teoksessa, anglosaksisella koulutussosiologisella kirjallisuudella, joka todistaa koulujen eriarvoistumisesta ja luokkaeroja vahvistavasta luonteesta.

Vanhempien käsitykset valikoinnista ja mielipiteet kouluvalintapolitiikasta osoittavat, että suomalaiset arvostavat koko ikäluokan yhteisiä oppimiskokemuksia, kanssakäymistä, hyvinvointia ja turvallisuutta enemmän kuin lahjakkuuksien karsintaa ja sparraamista. Kirjoituksessa keskustellaan muita enemmän suomalaista peruskoulua toimijoiden näkökulmasta käsittelevän tutkimuksen kanssa.

Risto Rinteen, Heikki Silvennoisen, Janne Varjon ja AnnaKaisa Berishan kirjoitus arvioi napakasti kouluvalintojen yhteyttä vanhempien poliittiseen identifioitumiseen. Otsikko on hiukan harhaanjohtava, sillä suuri osa kirjoituksesta esittelee erilaisia puolueen määrittelyjä suhteessa yhteiskuntaluokkaan ja kommentoi puolueiden vaaliohjelmien mainintoja kouluvalinnoista.

Näistä valitettavan irrallisesti kirjoittajat erittelevät kyselyaineistosta vanhempien asenteita
SUOMALAISET

ARVOSTAVAT KOKO

IK ̈̈LUOKAN

YHTEISI $\ddot{A}$ OPPIMIS-

KOKEMUKSIA

ENEMMÄN KUIN

LAHJAKKUUKSIEN

KARSINTAA JA

SPARRAAMISTA.

kouluvalinnan vapauteen ilmaistujen puoluekantojen perusteella. Yleiseen valikointiin ja oman lapsen kouluvalintaan kohdistuvat asenteet näyttävät ristiriitaisilta. Tutkijat ehdottavat, että korkea koulutustaso on oman lapsen kohdalla ratkaisevampaa kuin puoluesamaistuminen.

\section{YHTEISKUNTALUOKKA} YHDISTÄÄ

Lukijana voi ihmetellä, miksi teos ei ala kirjoitusten pohjana olevien hankkeiden ja kirjoittajakuntaa perustavimmin yhdistävästä osasta Kouluvalinnat ja yhteiskuntaluok$k a$, kun edeltävien osien analyysit nojaavat pitkälti siihen.

Heikki Silvennoinen, Risto Rinne, Sonja Kosunen, Mira Kalalahti ja Piia Seppänen työstävät artikkelissaan yhteiskuntaluokkien jäsennyksen erityistesti Stephen Ballin brittiläisen keskiluokan koulutusstrategioita luonnehtivan asetelman sekä Jani Erolan suomalaisten 
luokkaidentifioitumista koskevan tutkimuksen pohjalta. Suomessa "kouluvalintamekanismi" vain aktualisoituu painotetun opetuksen valinnoissa. Vaikka kirjoittajat korostavat (jo aiemmissa osissa todettujen) koulutusvalinta-asenteiden yhteyttä määrittelemiinsä yhteiskuntaluokkiin, asiaan perehtynyt lukija voi tutkijoiden tapaan myös ihmetellä erojen vähäisyyttä.

Päällimmäiseksi löydökseksi tässäkin osassa näyttää jäävän vanhempien "vahva universalismin periaatteen kannatus". Siinä erityisesti alempien luokkien vanhemmat toivovat koulu- ja opetusryhmävalintojen huomioivan lastensa erilaisuutta aiempaa paremmin. Osassa teksteistä käydään mielenkiintoista keskustelua tutkimuskirjallisuuden kanssa ja spekuloidaan (perus)koulun funktiota yhteiskuntaluokkien rakentumiseen, mutta niiden kiinnittyminen aineistoon jää ohueksi.

\section{HAJANAINEN AINEISTO}

Neljännessä osassa Piia Seppäsen, Mira Kalalahden, Risto Rinteen ja Hannu Simolan artikkelia Johtopäätökset - lohkoutuva suomalainen peruskoulu vanhempien näkemänä on hyvä lukea yhdessä liitteenomaisen Aineistot-luvun kanssa.

Aiemmissa osissa virinnyt odotus vanhempien asenteiden, kokemusten ja mielipiteiden suhteuttamisesta alueellisten ja paikallisten koulu(tus)politiikkojen todellisuuteen, tasa-arvopuheen ja -politiikan kerrostumiin sekä suomalaista koulua, opettajia ja oppilaita koskevaan muuhun tutkimukseen ei täyty. Tätä ehkä selittää johtopäätösten jonkinasteinen irrallisuus aineiston muodostumisen teoreettisista lähtökohdista.

Kuudesluokkalaisten vanhemmille tehdyt haastattelut Vantaalla, Turussa ja Espoossa (vuosina 2009-2011) ja kyselyt Helsinkiin, Espooseen, Tampereelle, Turkuun ja Vantaalle (vuonna 2012) kohdistuvat eri kohdejoukkoihin. Kyselyyn osallistuminen vaihteli yhdeksästä kolmeenkymmeneenviiteen prosenttiin. Molemmat aineistot painottivat ylempää keskiluokkaa. Kaupunkien koulupolitiikkaa ilmentävää - ja historiaan kiinnittävää - aineistoa ei käytetty. Paradigmaattisesta yhtenäisyydestä huolimatta laajan aineiston työstäminen heterogeenisen tutkijakunnan yhteisiksi tulkinnoiksi ja johtopäätöksiksi ei vaikuta ongelmattomalta.

\section{ELEFANTIN TUNNUSTELUA}

Lohkoutuva peruskoulu -teoksessa peruskoulu näyttää tutun tarinan kuvailemalta elefantilta, jota tutkimushankkeet ja kirjoittajat koettavat tunnustella kukin omilla lähestymistavoillaan ja aineistoillaan. Pyrkimyksenä on yhteisen kuvauksen tuottaminen, vaikka aineistot ja löydökset eivät antaisikaan siihen kiistatonta oikeutusta. Tutkijaryhmä toteaa toistuvasti nojaavansa niin Pierre Bourdieun ja hänen seuraajiensa ranskalaisen yhteiskunta- ja koulutushistorian kuin Stephen Ballin ja kumppanien anglosaksisiin, keskiluokkaistumisen ja koulutuksen markkinoistumisen teoretisointeihin.
Jos suomalaisten vanhempien asenteita, kokemuksia ja käsityksiä koskeva empiirinen aineisto ei yksiselitteisesti niihin taivu, voisiko johtopäätöksenä olla myös tarve tarkistaa tutkimusten teoreettisia ja metodologisia lähtökohtia? Voisivatko kirjoittajat "aikojen ja politiikkojen pahentumisen" vakuuttelun sijasta harkita myös "koulun" ja "peruskoulun" merkitysten - myös koulu- ja koulutuspolitiikkojen kontekstoimista paikallisesti, kulttuurisesti ja historiallisesti?

Teoksessa ja sen pohjana olevissa tutkimuksissa peruskoulu ja yleisemmin kasvatukselliset instituutiot ja organisaatiot - näyttää jäävän ulkopuolisen todellisuuden omalakisesti säätelemäksi "mustaksi laatikoksi". Kasvatuksen maailmassa toimeenpannaan globaaleja liiketaloudellisia intressejä edistävää politiikkaa, jota abstraktit yhteiskuntaluokat näyttävät uusdarwinistisesti ja laskemoiden käyttävän hyväkseen uusintaakseen asemansa.

Vaikka tutkimusten kyselyaineisto oli vino, se olisi myös voinut herättää kysymyksiä omaksuttujen yhteiskuntaluokitusten osuvuudesta ja kasvatuksellisten arvostusten kompleksisesta luonteesta. Myös haastatteluaineisto olisi kuvausten ja näytteiden perusteella voinut toimia virikkeenä koulun "mustan laatikon" avaamiseen: erilaisten toimijoiden - vanhempien, oppilaiden, alueilla asujien, opettajien, koulupoliitikkojen ja niin edelleen - halujen, toiveiden, ajatusten, vuorovaikutuksen ja kommunikaation, toiminnan ja 
käytänteiden, jännitteiden ja ristiriitojen tunnistamiseen. Tämä olisi voinut lisätä kiinnostusta tarkastella myös muita tutkimuksia, ja lisätä keskustelua niiden tulkintojen kanssa.

\section{KOULUTUKSELLISEN TASA-ARVON DILEMMA}

Lohkoutuva peruskoulu -teos ilmentää suomalaisen koulutussosiologian 1980-luvulta lähtien vahvistunutta tutkimuslinjaa, jossa on pyritty osoittamaan koulutuksen luokka-asemia sitkeästi uusintava luonne. Tutkimuksen työkaluina ovat olleet erityisesti opiskelijoiden (tai vanhempien ja perheiden) koulutusvalintoja kuvaavat viralliset tilastot.

Käsillä olevassa teoksessa hyödynnetään kuitenkin ensi sijassa vanhemmille suunnattuja kyselyjä ja haastatteluja. Vaikka tilastojenkin muodostuminen perustuu asiantuntijoiden tulkintoihin, kysely- ja haastatteluaineiston tulkinnallisuus on johtopäätösten kannalta paljon kriittisempää. Kirjoittajat toteavat tarkastelevansa vastaajien asenteita (mielipiteitä) ja puhetta, mutta tulkitsevat ne käytännössä tutkijoiden muotoilemien yhteiskuntaluokkien sukupolvet ylittäviksi asemien uusintamisstrategioiksi.

Mitä tutkijat ja vastaajat tarkoittavat peruskoululla ja sen lohkoutumisella? Jo syntyessään suomalainen peruskoulu rakentui koko ikäluokalle tarkoitetun kuuden ensimmäisen luokan (kansakoulun) ja oppikoulun viiden ensimmäisen luokan (keskikoulun) pohjalta. Aivan fyysisestikin kuusiluokkaiset ala-asteet toimivat aikaisemmissa kansakouluissa, oppilaiden asuinalueen lähikouluissa.

Kolmiluokkaiset yläasteen koulut eivät ole alun perinkään olleet "lähikouluja", vaan ne kokosivat oppilaat entisten oppikoulujen sijoille, yleensä lukio naapurinaan. Vaikka oppiainekoostumus hiukan muuttui, pysyivät koulut myös sisällöllisesti eriytyneinä.

Vaikka useissa kunnissa on jo vuosia pyritty yhtenäistämään peruskoulua yhdistämällä ala- ja yläasteet (ilmiö, jonka kirjoittajat sivuuttavat), kohdekaupungeissa ne näyttävät säilyneen varsin erillisinä. Tarkoittavatko tutkijat peruskoulun lohkoutumisella vanhempien nimenomaan yläkouluun kohdistuvia puheita ja asenteita?

Lohkoutumisella kirjoittajat viittaavat koulutuksellisen tasaarvon murentumiseen, mutta mitä lohkoutumisen ja tasa-arvon määritelmät ja tulkinnat heille ja vastaajille tarkoittavat? Haastatteluaineiston vanhemmat ilmaisevat yleistä huolta asuinalueiden sosiaalisesta ja kulttuurisesta lohkoutumisesta. Tällöin lähialakoulut saattavat noudattaa aiempaa vähemmän "sosiaalisen sekoittamisen" periaatetta. Isoihin yläkouluihin siirtymisestä tulee huolenaihe niin murrosikään eteneville lapsille kuin heidän vanhemmilleen ja uusille opettajille.

On sääli, etteivät kirjoittajat tartu tarkasteltavien kaupunkien kaavoitus- ja asuntopolitiikkaan (ja alue- ja ympäristöpoliittiseen tutkimukseen). Koulutususkon kritiikistä huolimatta he näyttä- vät sälyttävän peruskoululle kovin paljon valtaa yleisen yhteiskuntapolitiikan seurausten korjaamisessa. Sen sijaan vanhempien asenteissa ja puheissa voisi halutessaan nähdä tasa-arvoa painottavan peruskoulun vaikutuksia.

Simola ym. nostavat artikkelissaan esiin tasa-arvopuheiden moninaisuuden. Kirjoittajat näyttävät kuitenkin samaistavan oppilaiden koulutuksellisen tasaarvon samanlaiseen kohteluun, jonka osallistuminen oppiaineiden painotettuun opetukseen romuttaa. Vanhempien enemmistö pitää yhteistä koulukokemusta tärkeänä arvona, vaikka siihen sisältyisi oppilaiden erilaisuuteen perustuvaa eriytynyttä kohtelua. Kirjoittajat katsovat painotusten tarkoittavan oppilaan parempia mahdollisuuksia edetä akateemisiin opintoihin, jotka itsessään ja tuottamissaan yhteiskunnallisissa asemissa ovat muita opintoja arvokkaampia. Saman kohtelun ja sosiaalisen sekoittamisen periaate tarkoittaisi kai kaikkien opintojen, tohtorikoulutusta myöten, avaamista kaikille halukkaille - tai peruskoulun mukaisesti velvollisuutena osallistua niihin.

Tämä muistuttaa perinteistä sukupuolten tasa-arvokeskustelua, jossa unohdetaan kysymys arvoista, joita tavoitellaan. Voisiko olla mahdollista, että ainakin osa vanhemmista ja perheistä arvostaa opintoja silloin, kun ne johtavat ammatillisiin opintoihin tai "alempiin” yhteiskunnallisiin asemiin?

Aineistossa on viitteitä siitä, että tällaisia vanhempia ja perheitä löytyy myös "korkeammista" 
yhteiskuntaluokista. Niin akateemisten työmarkkinoiden heikentyminen kuin kriittisyys kilpailevaa elämäntapaa kohtaan saattavat näkyä vanhempien ja nuorten jo vuosia kasvaneessa kiinnostuksessa ammattikouluun peruskoulun jälkeisenä vaihtoehtona.

\section{LOHKOUTUVAT DISKURSSIT?}

Kuten Piia Seppänen ym. artikkelissaan toteavat, kansalliseen, alueelliseen ja yksilölliseen taloudelliseen kilpailukykyyn keskittyvä koulutuspoliittinen puhe näyttää kaukaiselta, jopa vastakkaiselta vanhempien, oppilaiden ja opettajien kasvatukselliseen puheeseen verrattuna. Vaikka oppilaiden erilaisuutta toivotaan tuettavan, painotusten tarjoamispolitiikka vaikuttaa monista pikemminkin valintaan pakottamiselta kuin oikeudelta valintaan. Näyttää kuin vanhemmat haluaisivat pitkittää lasten pysymistä yhteisöllisyy- den ja solidaarisuuden eetoksen virittämässä peruskoulussa, joka katkeaa yksilöllisen ja keskinäisen kilpailun logiikalla jatkuvaan koulutus- ja työelämään.

Huippuosaamisen korostus lukio- ja ammatillisessa koulutuksessa sekä korkeakoulutuksessa on epäilemättä varsinkin valistuneiden ja tiedostavien vanhempien tiedossa. Ehkä jatkossa kannattaisi tutkailla myös peruskoulun jälkeisen elinikäisen oppimisen ja koulutuksen doktriinien kumulatiivisia, joiltain osin vanhempien välittämiä, vaikutuksia yksilöiden ja ryhmien "kouluvalintoihin" ja niiden moninaisiin yksilöllisiin ja yhteiskunnallisiin seurauksiin.

Lohkoutuva peruskoulu-teos on voimakas (ellei jopa arvovaltainen) puheenvuoro koulutuksellisen kilpajuoksun lähes vääjäämättömästä jatkuvuudesta. Sen oppineet ja historiallisesti taustoitetut artikkelit ovat hyödyllistä luettavaa niin tutkijoille kuin opiskelijoille.
Taustalla olevien tutkimusten avautumista ja esitettyjen väitteiden uskottavuutta olisi parantanut teoksen osien tiukempi suhteuttaminen toisiinsa, päällekkäisyyksien ja toistojen karsiminen sekä systemaattinen eteneminen tutkimusasetelmasta keskeisiin johtopäätöksiin. Lisäksi koko paketin olisi voinut tiivistää - edesmenneen Seppo Niemelän sanoin: "puolet pois ja loppu lyhennettävä.

Artikkelien itsenäisyys voi helpottaa tietyistä aiheista kiinnostuneiden lukijoiden paneutumista vain valikoituihin artikkeleihin. Ehkä "peruskoulu-elefantin" identifioimiseksi tutkimusta kannattaisi silti jatkaa myös saattamalla eri viitekehyksillä ja työkalupakeilla kasvatusta tutkivat yhteisten pöytien ääreen keskustelemaan.

Anja Heikkinen

$K T$, FM, professori

Tampereen yliopisto 